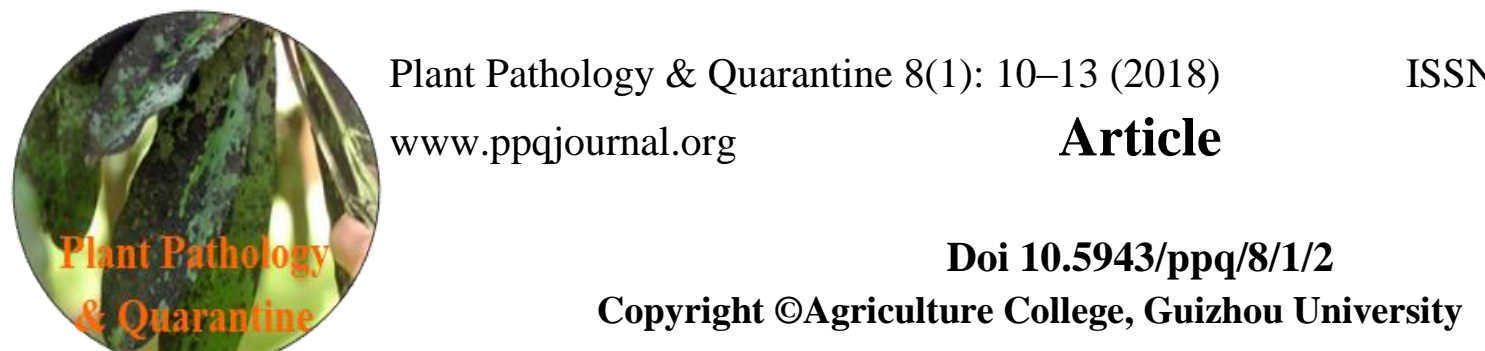

\title{
Phyllosticta capitalensis sporulating on ginkgo leaves in Taiwan
}

\section{Kirschner R}

Department of Biomedical Sciences and Engineering, National Central University, Zhongli District, 320 Taoyuan, Taiwan

Kirschner R 2018 - Phyllosticta capitalensis sporulating on ginkgo leaves in Taiwan. Plant Pathology \& Quarantine 8(1), 10-13, Doi 10.5943/ppq/8/1/2

\begin{abstract}
Formation of pycnidia by Phyllosticta capitalensis on living and dead leaves of Ginkgo biloba is recorded for the first time, based on morphology and the internal transcribed spacer sequence (ITS) of the ribosomal RNA gene of samples from Taiwan. Although the fungus is recorded as a widespread endophyte and weak pathogen from numerous plants, on ginkgo it has hitherto only been known as an endophyte in Japan. Phyllosticta capitalensis is the single verified Phyllosticta species on this host. Another fungus from ginkgo, the invalidly published Pseudocercospora ginkgoana is validated here.
\end{abstract}

Key words - Botryosphaeriales - Diaporthe - Guignardia - Phoma - plant pathogen

\section{Introduction}

Leaves of ginkgo (Ginkgo biloba L.) can be colonized by fungi from a wide range of systematic groups, such as Chytridiomycota (Synchytrium macrosporum Karling; Karling 1964), Ascomycota (several species; Kirschner \& Okuda 2013), and Basidiomycota (Bartheletia paradoxa G. Arnaud ex Scheuer et al.; Scheuer et al. 2008, Kirschner \& Okuda 2013, Koukol \& Lotz-Winter 2016). Although Bartheletia paradoxa was claimed as a "living fossil" (Scheuer et al. 2008), the hitherto single known fungus on fossil ginkgo leaves is a microthyriaceous ascomycete without known extant counterpart (Sun et al. 2015). In our brief account of fungi on ginkgo leaves (Kirschner \& Okuda 2013), we did not go into details about the records of Phyllosticta and overlooked a record of Ph. capitalensis from Japan (Motohashi et al. 2009). A recent finding of a Phyllosticta specimen on living and dead ginkgo leaves in Taiwan prompted complementing our previous notes about fungi on ginkgo. In addition, our invalid publication of Pseudocercospora ginkgoana is validated.

\section{Materials \& Methods}

Attached and freshly fallen leaves of Ginkgo biloba with leaf spots were collected on the campus of National Central University in Taoyuan City, Taiwan, and investigated immediately with a dissecting microscope. Conidial masses visible on the top of pycnidia were picked up with a flamed acupuncture needle and transferred to corn meal agar (CMA, Fluka) with 0.2\% chloramphenicol. Dried specimens were deposited at the fungal collection of the Museum of Natural Science, Taichung, Taiwan (TNM). For microscopic investigation, fresh specimens were mounted in $10 \%$ aqueous $\mathrm{KOH}$ and stained with $1 \%$ aqueous phloxine B. Measurements of conidia 
were made with 30 replicates and given as mean value \pm standard deviation and extreme values in brackets. Other values are presented as extreme values. DNA was isolated from culture material derived from specimen R. Kirschner 4351 with the Genomic DNA Spin Kit (Plant; Bioman Scientific Co., Taiwan) according to the manufacturer's instructions. Amplification of the internal transcribed spacers (ITS) of the ribosomal RNA gene, sequencing of the amplicons, and editing of the sequences were done as in Kirschner \& Okuda (2013). Sequence-based identification was made by searching with the BLAST algorithm in GenBank. The ITS sequence was deposited in GenBank under MG550984.

\section{Results}

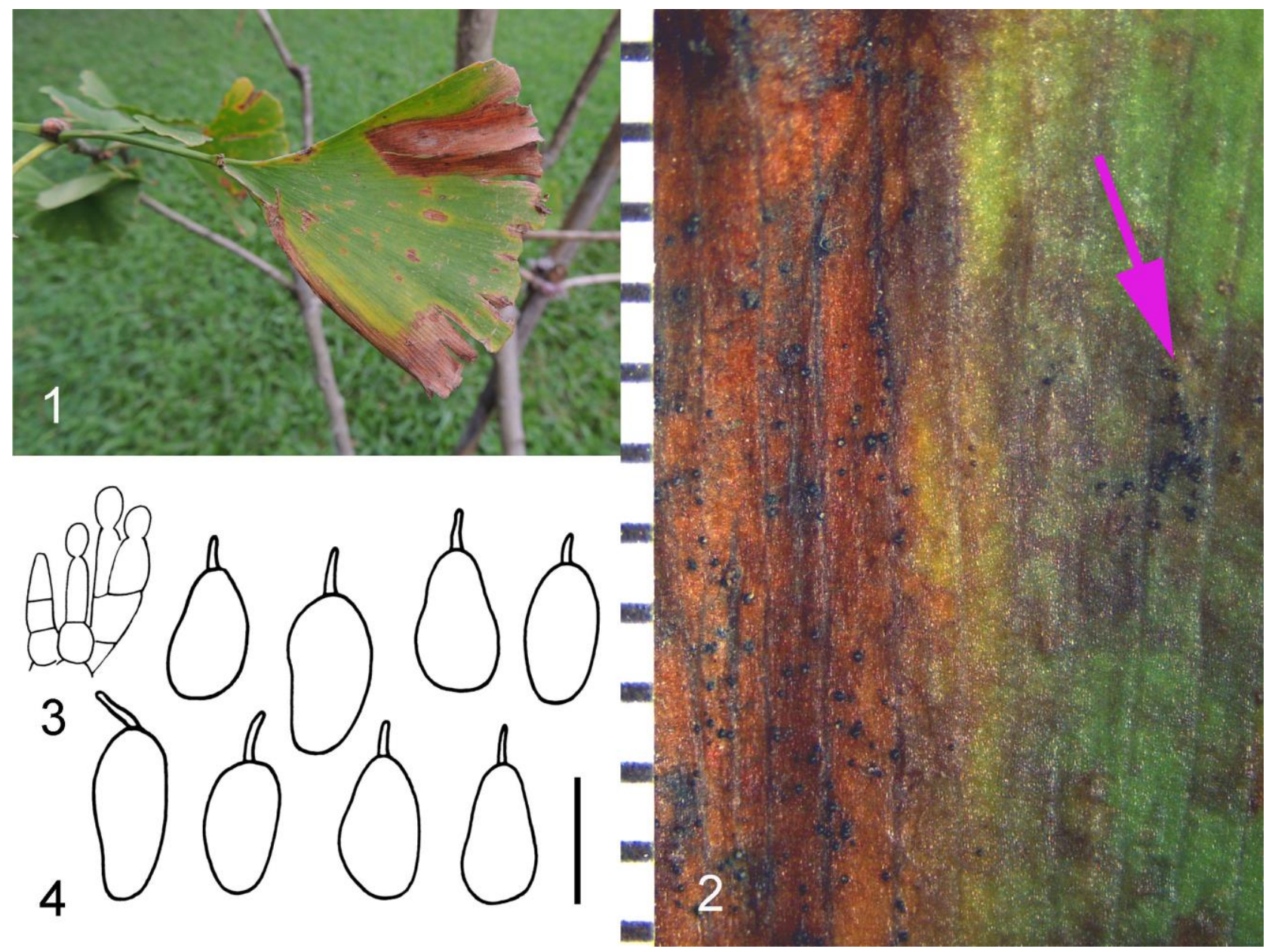

Figs 1-4 - Phyllosticta capitalensis on Ginkgo biloba. 1, 2, 4 R. Kirschner 4351. 3 R. Kirschner 4513. 1 Infected leaf attached to a ginkgo tree. 2 Black pycnidia on the brown and green area (arrow) of the same leaf. 3 Conidiophores. 4 Conidia. - Bar 3, $4=10 \mu \mathrm{m}$.

Phyllosticta capitalensis Henn. (for synonyms see Wulandari et al. 2013)

Figs 1-4

Pycnidia on green as well as brown discolored parts of the same leaf, particularly numerous on fallen brown leaves, amphigenous, developing supepidermally, rupturing epidermis during maturation, globose, black when seen with low magnification, brown in transmitted light in the light microscope, 70-120 $\mu \mathrm{m}$ high, $85-125 \mu \mathrm{m}$ wide, wall 7-10 $\mu \mathrm{m}$ thick, composed of 2-3 layers of pale to dark brown textura epidermoidea, cells $6-20 \times 3-13 \mu \mathrm{m}$, ostiole apical, not raised, circular, 10-15 $\mu \mathrm{m}$ diam. Internal hyphae intercellular, pale to dark brown, smooth, 2-6 $\mu \mathrm{m}$ wide. Conidiogenous cells sessile or formed on 1-2 subtending, swollen cells, lageniform or cylindrical, hyaline, 3-5 $\times 2-3 \mu \mathrm{m}$. Conidia ellipsoidal to obpyriform, hyaline, 1-celled, smooth-walled, 9.5$12(-13) \times 6-7 \mu \mathrm{m}(\mathrm{n}=30)$, surrounded by a $0.5-1 \mu \mathrm{m}$ thick mucilaginous sheath, bearing a single 
2-7 $\mu \mathrm{m}$ long apical appendage. Immature ascomata (sexual stage of the same species?) occurring on the same leaves.

When comparing ITS sequences exceeding $640 \mathrm{~b}$ in GenBank with BLAST, our sequence (657 b, GenBank MG550984) was 99-100\% identical to those of Ph. capitalensis/Guignardia mangiferae, with 0-2 deviating positions. The single sequence (EU167584) not labelled under this name, but as $P h$. elongata Weid. was corrected to Ph. capitalensis in Wikee et al. (2013). Searches excluding $P h$. capitalensis as search term only revealed the same sequence of "Ph. elongata", while other sequences published with species names were shorter than 640 b. Similarities with Phyllosticta species more commonly recorded from gymnosperms, namely Ph. abieticola Wikee \& Crous, Ph. abietis Bissett \& M.E. Palm, Ph. podocarpi Crous, Ph. podocarpicola Wikee, Crous, K.D. Hyde \& McKenzie, Ph. pseudotsugae L.E. Petrini, Petrini, Leuchtm. \& G.C. Carroll, and Ph. spinarum (Died.) Nag Raj \& M. Morelet, were considerably lower $(<92 \%)$.

Known distribution - On many diverse hosts in tropical and subtropical regions (Wikee et al. 2013, Wulandari et al. 2013).

Material examined - On living attached and dead fallen leaves of Ginkgo biloba L., Taiwan, Taoyuan City, Zhongli District, National Central University, N 24 58.050 E 121 11.605, 130 m MSL, 28 Oct 2016, R. Kirschner 4351 (TNM); ibid., 20 Nov 2017, R. Kirschner 4513 (TNM).

\section{Discussion}

Three Phyllosticta species have been recorded in the literature as endophytic(?) isolates from living leaf of G. biloba in Japan (Motohashi et al. 2009, not mentioned in Kirschner \& Okuda 2013), and from direct observation on leaves (Aa \& Vanev 2002). The two species with pycnidia on leaves, however, do not belong to Phyllosticta (Aa \& Vanev 2002):

\section{Phyllosticta ginkgo Brunaud}

On fallen leaves of G. biloba, France, conidia 3-8.5 × $2 \mu \mathrm{m}$ (Berlese, A.N.; Voglino, P., Sylloge Fungorum. Additamenta ad Volumina I-IV: i-iv, 1-484: 434, 1886)

"Small spored Phoma" (Aa \& Vanev 2002)

\section{Phyllosticta salisburyae ('salisburiae') Tassi}

On withering attached leaves of G. biloba, Italy, conidia 6-7 $\times 3 \mu \mathrm{m}$ (Saccardo, P.A., Sylloge Fungorum XVI: 847, 1902)

"Probably a Phoma or Phomopsis" (Aa \& Vanev 2002)

Since according to Aa \& Vanev (2002), these two species described under Phyllosticta rather belong to Phoma or Diaporthe, they have to be considered when species of the latter two genera from ginkgo will be revised taxonomically. Phyllosticta capitalensis is presently the single verified Phyllosticta species known from ginkgo leaves. Its occurrence as an endophyte(?) reported in the literature (Motohashi et al. 2009) and sporulation on living and dead leaves of ginkgo prior and after leaf-fall in autumn observed in this study, indicate a role as both endophyte and saprobe or weak pathogen in senescent leaves of ginkgo as suggested by Wulandari et al. (2013) for other host plants. In Taiwan, Ph. capitalensis has been recorded on fruits of persimmon (Dispyros kaki; Duan et al. 2017). A record on Citrus sp. in Taiwan listed in Wikee et al. (2013) could not be traced in the given references and may be doubtful.

By courtesy of P. Kirk (Index Fungorum) and C. Bensch (MycoBank), we realized that we had presented the wrong repository identifier MB518046 for Pseudocercospora ginkgoana R. Kirschner in Kirschner \& Okuda, Mycol. Progr. 12: 423 (2013), rendering the name invalid according to Art. 42.1 of the International Code of Nomenclature for algae, fungi and plants. By publishing a new repository accession, the name is validated here as Pseudocercospora ginkgoana R. Kirschner, sp. nov., under the new identifier MycoBank MB818606, with its holotype (Kirschner et al. 3561, TNM) and description as given in Kirschner \& Okuda, Mycol. Progr. 12: 423 (2013). The TNM specimen accession has been designated as F0026006. 


\section{Acknowledgements}

This work was financed by the Ministry of Science and Technology, Taiwan (NSC102-2621B-008-001-MY3 and MOST 102-2621-B-008-001-MY3). Students of NCU are thanked for technical assistance in the laboratory. The suggestions from P. Kirk (Index Fungorum) and C. Bensch (MycoBank) concerning the validation of Pseudocercospora ginkgoana are particularly appreciated.

\section{References}

Aa HA van der, Vanev S. 2002 - A revision of the species described in Phyllosticta. Centraalbureau voor Schimmelcultures, Utrecht.

Duan C-H, Chang C-M, Su C-C, Pan H-R, Wang C-C. 2017 - Phyllosticta capitalensis causes black spot of persimmon (Diospyros kaki) fruit in Taiwan. Australasian Plant Disease Notes 12:36, 1-4. Doi 10.1007/s13314-017-0263-4.

Karling JS. 1964 - Synchytrium. New York, Academic Press.

Kirschner R, Okuda T. 2013 - A new species of Pseudocercospora and new record of Bartheletia paradoxa on leaves of Ginkgo biloba. Mycological Progress 12, 421-426.

Koukol O, Lotz-Winter H. 2016 - Secondary conidia observed in Bartheletia paradoxa. Czech Mycology 68(1), 79-84.

Motohashi K, Inaba S, Anzai K, Takamatsu S, Nakashima C. 2009 - Phylogenetic analyses of Japanese species of Phyllosticta sensu stricto. Mycoscience 50, 291-302.

Scheuer C, Bauer R, Lutz M, Stabentheiner E, Melnik VA, Grube M. 2008 - Bartheletia paradoxa is a living fossil on ginkgo leaf litter with a unique septal structure in the Basidiomycota. Mycological Research 112, 1265-1279.

Sun C, Taylor TN, Na Y, Li T, Krings M. 2015 - Unusual preservation of a microthyriaceous fungus (Ascomycota) on Sphenobaiera (ginkgophyte foliage) from the Middle Jurassic of China. Review of Palaeobotany and Palynology 223, 21-30.

Wikee S, Lombard L, Crous PW, Nakashima C, Motohashi K, Chukeatirote E, Alias SA, McKenzie EHC, Hyde KD. 2013 - Phyllosticta capitalensis: a widespread endophyte of plants. Fungal Diversity 60, 91-105.

Wulandari NF, Bhat DJ, To-anun C. 2013 - A modern account of the genus Phyllosticta. Plant Pathology \& Quarantine 3(2), 145-159. Doi 10.5943/ppq/3/2/4. 